\title{
Polish Language
}

National Cancer Institute

\section{Source}

National Cancer Institute. Polish Language. NCI Thesaurus. Code C154079.

An Indo-European West Slavic language spoken primarily in Poland as the native language of the Poles. 